\title{
Authors' Reply to Whitlock: Perispinal Etanercept for Post-Stroke Neurological and Cognitive Dysfunction: Scientific Rationale and Current Evidence
}

\author{
Tracey A. Ignatowski • Robert N. Spengler • \\ Edward Tobinick
}

Published online: 6 November 2014

(C) The Author(s) 2014. This article is published with open access at Springerlink.com

The authors of this article have each been involved, over the course of more than a decade, in the basic science and/ or clinical investigation of tumor necrosis factor (TNF) mechanisms involving the brain, i.e. in neuroinflammation research [1-16]. One of the aims of our 2014 review was to bring together the increasing scientific evidence, from multiple fields of investigation and multiple academic centers that support a central role of neuroinflammation in the pathogenesis of post-stroke neurological dysfunction [17]. In 2014, neuroinflammation has emerged as an area of increased international research interest, with intense interest in Europe and a new neurology journal devoted to this specific field [18-20].

Novel scientific discoveries, synthesized with previous scientific evidence, provide a framework for the scientific rationale underlying the rapid effects of perispinal etanercept on brain pathology $[9,13,16,21-28]$. This framework includes the discovery, in 2011, through the use of functional magnetic resonance imaging (fMRI), that within $24 \mathrm{~h}$ after neutralization of TNF by systemic intravenous administration of infliximab, nociceptive activity in the thalamus and somatosenoric cortex, as well as activation of the limbic system, was blocked [22]. In 2013, a single systemic subcutaneous dose of another biologic TNF

T. A. Ignatowski

Department of Pathology and Anatomical Sciences and Program for Neuroscience, School of Medicine and Biomedical Sciences,

The State University of New York, Buffalo, NY, USA

R. N. Spengler

NanoAxis, LLC, Clarence, NY, USA

E. Tobinick $(\bowtie)$

Institute of Neurological Recovery, 2300 Glades Road Suite

305E, Boca Raton, FL 33431, USA

e-mail: nrimed@gmail.com inhibitor, certolizumab pegol, was found to produce a rapid decrease in disease-related fMRI brain activity in rheumatoid arthritis patients, which preceded both clinical and structural responses to the drug [28]. Just this week it was reported that a single dose of an antidepressant, the selective serotonin reuptake inhibitor escitalopram, dramatically alters functional connectivity throughout the whole brain in healthy subjects within 3 hours of the dose [23]. The rapid and profound effect that antidepressant drugs have on the production of TNF in the brain was first demonstrated by Ignatowski and Spengler in 1994 [29]. Antidepressant administration (desipramine) to rats prevented neuron-associated TNF production, as demonstrated by staining for TNF in the locus coeruleus and hippocampus [30]. This was demonstrated to occur within $24 \mathrm{~h}$ after drug administration [29, 30]. These findings, along with the scientific evidence previously considered in our 2014 review, demonstrate that rapid effects of perispinal etanercept are entirely compatible with brain physiology as it is understood today $[9,13,14,16,17,21,23,25-27$, 31-37].

Whitlock has written a letter commenting on our 2014 review [38], which begins with a misconception regarding the well-known criteria that Sir Austin Bradford Hill originally developed to facilitate evaluation of causality [38, 39]. We utilized the Hill criteria in our 2014 review [17]. Contrary to the assertion of Whitlock, expert opinion supports use of the Bradford Hill criteria as one method to assist in the evaluation of the strength of evidence supporting therapeutic causality [40-43]. This modification of the Hill criteria for therapeutic evaluation was not the authors' invention; rather, this use of the Hill criteria was suggested by central figures in the evidence-based medicine paradigm (Howick and Glasziou) and others [40-44]. As Williams observed in 2001: 
The narrow definition of epidemiology is the study of the distribution of diseases in a population. The broader definition - an inductive science of biological inferences derived from observations-is more appropriate when relating EBM principals to clinical decision making .... The use of Bradford-Hill Criteria enhances evidence-based recommendations [42].

Explicit consideration of the Bradford Hill criteria may facilitate appreciation of the scientific rationale and evidence regarding pathophysiology underlying innovative therapeutic decision making [17, 40, 41, 43, 45].

Randomized clinical trial (RCT) evidence is essential for regulatory approval but RCTs that involve innovative methods of drug delivery may only be possible with direct involvement of the drug manufacturer [46]. A blind insistence that the RCT constitutes the only valid form of evidence, as Whitlock suggests, does a disservice to science and the public [40,41, 43, 47-52]. The discovery of a new use of an existing drug often begins with an initial observation made in the course of clinical practice when utilizing the drug off-label [53, 54]. Evidence development commonly involves open-label observational studies; this was the case for the first approved indication of the biologic TNF inhibitors [55]. Rigorous observational studies, including case studies and case series, are a classical approach that may provide early evidence for therapeutic effectiveness before formal RCTs are conducted [40-44, $47-50,53,56-58]$. It is not scientifically justifiable to ignore the valid evidence contained in observational studies when evaluating therapeutic interventions, particularly for emerging indications [41, 43-45, 47, 49-51, 56-60]. As multiple authors have stated:

Sometimes the effect of a medical intervention is so surprisingly strong, against the background knowledge of 'usual prognosis', that a case report or case series suffices to convince [57].

Case reports and case series have their own role in the progress of medical science. They permit discovery of new diseases and unexpected effects (adverse or beneficial) as well as the study of mechanisms, and they play an important role in medical education. Case reports and series have a high sensitivity for detecting novelty and therefore remain one of the cornerstones of medical progress; they provide many new ideas in medicine [58].

Given that randomized, controlled trials have not and often cannot be done for many clinical interventions, much of the clinical care provided in neurology (and all other specialties in medicine) would necessarily be considered unsubstantiated, if observational studies are discounted from consideration ... the popular belief that randomized, controlled trials inherently produce gold standard results, and that all observational studies are inferior, does a disservice to patient care, clinical investigation, and education of health care professionals [49].

As recently restated in an opinion viewpoint published in JAMA Neurology, “... over-reliance on RCTs is similar to resting all of health care evidence on a one-legged stool" $[41,47]$. The authors concluded:

"Most health care decisions, especially by clinicians and patients, are based on incomplete evidence. This process could be improved with better access to transparent, credible, and concise yet complete summaries of the available evidence and its strength, whether or not it is conclusive and whether or not it includes RCTs" [47].

Authorities in the field of evidence-based medicine have specifically addressed the fact that some treatments have effects that are "... so dramatic that randomised trials are unnecessary" [43]. Each of the authors has personally observed the unmistakable rapid neurological improvement produced by perispinal etanercept in patients with chronic, stable, baseline neurological dysfunction [8-10, 24, 26, 27, $32,61]$. The distinctive pattern of neurological improvement that often ensues following perispinal etanercept injection, documented in published digital video and written format, provides striking scientific evidence of a therapeutic effect $[32,62] .{ }^{1}$ These results are supported by a diverse variety of additional clinical and basic science studies that have specifically utilized etanercept as a therapeutic agent [8-12, 14, 17, 21, 24-27, 32, 61, 63-78]. Our recent review presents a detailed overview of the scientific evidence that supports the mechanistic reasoning utilized $[17,45,48]$. There are no gaps in the pathophysiological mechanisms discussed; the inferential chain is complete $[17,48]$. The published, peer-reviewed perispinal etanercept scientific literature provides more than a decade of scientific support that includes detailed case studies documenting rapid and sustained neurological improvement in patients with neurological dysfunction that had long been unchanged prior to perispinal etanercept administration [814, 16, 24-27, 32, 61, 74-76, 79-82].

These case reports are not isolated cases. Rather these results have been replicated, confirmed and extended [17, $25,26,32]$. Four years of clinical experience with many additional patients with chronic brain dysfunction after stroke, intracerebral hemorrhage, and acquired brain injury has followed the documented pattern of statistically

\footnotetext{
1 Further digital video documentation at https://vimeo.com/user5534 662/review/85796991/4385338257; https://vimeo.com/user5534662/ review/85477199/2aa9b2c6f8 and http://www.vimeo.com/18550399.
} 
significant improvements in motor impairment, cognition, psychological/behavioural function, aphasia and pain following perispinal etanercept injection reported in the 629-patient study of 2012 [17, 25, 26, 32]. Moreover, since publication of the 2012 study [26], the peer-reviewed medical literature has provided further basic science and clinical support for the scientific rationale $[6,7,17,21,26$, 31-37, 47, 59, 63, 65-67, 69, 71, 75, 83-120]. As Lei et. al. and Kathirvelu and Carmichael stated in 2013 and 2014, respectively:

Antagonism of pro-inflammatory cytokines by specific antibodies represents a compelling therapeutic strategy to improve neurological outcome in patients after intracerebral hemorrhage [107].

With direct blood extravasation into brain, secondary inflammation is a substantial feature. Drugs which reduce neuroinflammation enhance functional recovery [94].

As a noted authority in the field of TNF and brain dysfunction has written:

... the years-long interval between the stroke event and rapid clinical improvement described in these patients is consistent with experimental evidence that TNF generation persists in the CSF for very much longer (10 months plus) than in the serum (gone in $6 \mathrm{~h}) . .$. In this report each patient's pre-treatment state provided an internal control. In practice, these individual pre-treatment comparisons are highly valid, since the likelihood of rapid spontaneous return of function is remote this long after the stroke event. Moreover, since no two stroke outcomes are the same, such internal controls allow precise before and after clinical comparison in a phenotypically heterogeneous condition [121].

There are now multiple, reported RCTs of etanercept for neurological indications that have shown etanercept to be superior to placebo [64-66, 69, 71]. The character, magnitude and reproducibility of patient recovery documented following perispinal etanercept for chronic post-stroke neurological dysfunction is unequivocal evidence of a therapeutic effect $[8,9,12,17,24-27,32,74]$.

Whitlock further errs in his analogy comparing the effects of opiates and etanercept for neuropathic pain [38]. Exerting physiological effects that are distinct from those produced by opiates, TNF blockade using etanercept for treatment of neuropathic pain is a disease-modifying therapy that directly addresses a fundamental cause of the disorder, i.e. excess TNF [1, 63, 67, 68, 70, 72, 73, 77, 78, 84]. The authors each reported favorable effects of TNF blockade for the treatment of neuropathic pain, beginning more than a decade ago $[1,11,12,76]$. To date, there are four favorable double-blind, randomized controlled trials of etanercept for sciatica and other forms of spinal neuropathic pain that have been completed [64, 65, 69, 71]. In addition, the basic science evidence supporting a therapeutic, disease-modifying effect of etanercept for the treatment of neuropathic pain continues to increase [1, 63, $67,68,70,72,73,77,78,84]$. It is of significant interest that recent evidence suggests that the early analgesic effects of biologic TNF inhibitors in patients with rheumatoid arthritis may be directly mediated, not peripherally but rather by rapid brain effects of the biologic TNF inhibitor [22].

The rapid and dramatic neurological improvement repeatedly observed after perispinal etanercept administration in patients with chronic, post-stroke neurological dysfunction cannot be scientifically attributed to a placebo response, as Whitlock seems to suggest [1, 6, 8-10, 14, 16, 17, 21, 22, 24-27, 32, 36, 38, 41, 43, 44, 47, 56, 66, 75, 100, 118, 121-124]. In fact, a recent Cochrane review concluded:

There was no evidence that placebo interventions in general have clinically important effects [124].

Placebo effects do not produce the life-changing neurological improvements that have been documented and observed by each of the authors and others following perispinal etanercept injection [14, 25, 26, 32, 43]. In view of the distinctive character, quality and reproducibility of the clinical data, and the basic science evidence that supports the entire inferential chain, it would be a systematic error to deny the published, peer-reviewed evidence and characterize the reported clinical results of perispinal etanercept for post-stroke neurological dysfunction as anything less than a therapeutic breakthrough [8-12, 14, 17, 21, 24-27, 32, 48, 61, 63-78]. Those scientists who have recognized TNF antagonism for this indication as a "compelling therapeutic strategy"[107] are exactly in line with the guidance to "translate best neuroscience, including animal and human studies, into poststroke recovery research and clinical care" that is the published consensus recommendation of world stroke leaders [125].

Etanercept is providing billions of dollars of yearly income to its manufacturers. These drug manufacturers are the only entities that possess the combination of regulatory expertise and financial capability necessary to achieve regulatory approval for these essential novel therapeutic indications. The strength of the emerging evidence argues for joint industry-government-academic cooperation to facilitate overcoming the substantial translational barriers that exist for such an innovative therapeutic approach.

Acknowledgments and Conflict Disclosure Edward Tobinick has multiple issued and pending US and foreign patents, assigned to TACT 
IP, LLC, which claim methods of use of etanercept for the treatment of neurological disorders, including, but not limited to, US patents 6419944, 6537549, 6982089, 7214658, 7629311, 8119127, 8236306 and 8349323, all assigned to TACT IP, LLC; and Australian patent 758523. Dr. Tobinick is the founder of the Institute of Neurological Recovery (INR), a group of medical practices that utilize perispinal etanercept as a therapeutic modality, and also train physicians; he is also the CEO of TACT IP, LLC. Tracey Ignatowski and Robert Spengler have been expert witnesses for the INR. Tracey Ignatowski and Robert Spengler's professional activities include their work as CoDirectors of Neuroscience at NanoAxis, LLC, a company formed to foster the commercial development of products and applications in the field of nanomedicine, which include novel methods of inhibiting TNF. This article represents the authors' own work in which NanoAxis, LLC, was not involved. No funding was received for this letter.

Open Access This article is distributed under the terms of the Creative Commons Attribution Noncommercial License which permits any noncommercial use, distribution, and reproduction in any medium, provided the original author(s) and the source are credited.

\section{References}

1. Ignatowski TA, Covey WC, Knight PR, Severin CM, Nickola TJ, Spengler RN. Brain-derived TNFalpha mediates neuropathic pain. Brain Res. 1999;841(1-2):70-7.

2. Covey WC, Ignatowski TA, Knight PR, Spengler RN. Brainderived TNFalpha: involvement in neuroplastic changes implicated in the conscious perception of persistent pain. Brain Res. 2000;859(1):113-22.

3. Covey WC, Ignatowski TA, Renauld AE, Knight PR, Nader ND, Spengler RN. Expression of neuron-associated tumor necrosis factor alpha in the brain is increased during persistent pain. Reg Anesth Pain Med. 2002;27(4):357-66.

4. Reynolds JL, Ignatowski TA, Spengler RN. Effect of tumor necrosis factor-alpha on the reciprocal G-protein-induced regulation of norepinephrine release by the alpha2-adrenergic receptor. J Neurosci Res. 2005;79(6):779-87.

5. Ignatowski TA, Spengler RN. Cytokines in synaptic function. In: Berczi I, Szentivanyi A, editors. Cytokines and the brain. NeuroImmune biology. Vol 6. Amsterdam: Elsevier; 2008. p. 111-43.

6. Martuscello RT, Spengler RN, Bonoiu AC, Davidson BA, Helinski J, Ding H, et al. Increasing TNF levels solely in the rat hippocampus produces persistent pain-like symptoms. Pain. 2012;153(9):1871-82.

7. Ignatowski TA, Gerard BA, Bonoiu AC, Mahajan S, Knight PR, Davidson BA, et al., editors. Reduction of tumor necrosis factor (TNF) in the hippocampus alleviates neuropathic pain perception. Proceedings of the 4th International Congress on Neuropathic Pain; 2013. pp 29-35.

8. Tobinick E, Gross H, Weinberger A, Cohen H. TNF-alpha modulation for treatment of Alzheimer's disease: a 6-month pilot study. Med Gen Med. 2006;8(2):25.

9. Tobinick EL, Gross H. Rapid improvement in verbal fluency and aphasia following perispinal etanercept in Alzheimer's disease. BMC Neurol. 2008;8:27.

10. Tobinick EL, Chen K, Chen X. Rapid intracerebroventricular delivery of Cu-DOTA-etanercept after peripheral administration demonstrated by PET imaging. BMC Res Notes. 2009;2:28.

11. Tobinick EL, Britschgi-Davoodifar S. Perispinal TNF-alpha inhibition for discogenic pain. Swiss Med Wkly. 2003;133(11-12): $170-7$.
12. Tobinick E, Davoodifar S. Efficacy of etanercept delivered by perispinal administration for chronic back and/or neck discrelated pain: a study of clinical observations in 143 patients. Curr Med Res Opin. 2004;20(7):1075-85.

13. Tobinick E. Perispinal etanercept for treatment of Alzheimer's disease. Curr Alzheimer Res. 2007;4(5):550-2.

14. Griffin WS. Perispinal etanercept: potential as an Alzheimer therapeutic. J Neuroinflamm. 2008;5:3.

15. Maudsley S, Chadwick W. Progressive and unconventional pharmacotherapeutic approaches to Alzheimer's disease therapy. Curr Alzheimer Res. 2012;9(1):1-4.

16. Tobinick E. Deciphering the physiology underlying the rapid clinical effects of perispinal etanercept in Alzheimer's disease. Curr Alzheimer Res. 2012;9(1):99-109.

17. Ignatowski TA, Spengler RN, Dhandapani KM, Folkersma H, Butterworth RF, Tobinick E. Perispinal etanercept for poststroke neurological and cognitive dysfunction: scientific rationale and current evidence. CNS Drugs. 2014;28(8): 679-97.

18. Mohammadi D. INMiND: getting to the bottom of neuroinflammation. Lancet Neurol. 2013;12(12):1135-6.

19. NEURON. Call for proposals for "European Research Projects on Neuroinflammation", NEURON. 2014. http://www.neuroneranet.eu/en/522.php. Accessed 9 Oct 2014.

20. Ransohoff R. Call for papers: Neurology: Neuroimmunology and Neuroinflammation, a new neurology journal. Neurology. 2014;82:648-9.

21. Camara ML, Corrigan F, Jaehne EJ, Jawahar MC, Anscomb H, Baune BT. Effects of centrally administered etanercept on behaviour, microglia and astrocytes in mice following a peripheral immune challenge. Neuropsychopharmacology. 2014;. doi:10.1038/npp.2014.199.

22. Hess A, Axmann R, Rech J, Finzel S, Heindl C, Kreitz S, et al. Blockade of TNF-alpha rapidly inhibits pain responses in the central nervous system. Proc Natl Acad Sci USA. 2011;108(9):3731-6.

23. Schaefer A, Burmann I, Regenthal R, Arelin K, Barth C, Pampel A, et al. Serotonergic modulation of intrinsic functional connectivity. Cur Biol. 2014. doi:10.1016/j.cub.2014.08.024.

24. Tobinick E. Perispinal etanercept: a new therapeutic paradigm in neurology. Expert Rev Neurother. 2010;10(6):985-1002.

25. Tobinick E. Rapid improvement of chronic stroke deficits after perispinal etanercept: three consecutive cases. CNS Drugs. 2011;25(2):145-55.

26. Tobinick E, Kim NM, Reyzin G, Rodriguez-Romanacce H, Depuy V. Selective TNF inhibition for chronic stroke and traumatic brain injury : an observational study involving 629 consecutive patients treated with perispinal etanercept. CNS Drugs. 2012;26(12):1051-70.

27. Tobinick EL, Gross H. Rapid cognitive improvement in Alzheimer's disease following perispinal etanercept administration. J Neuroinflamm. 2008;5:2.

28. Rech J, Hess A, Finzel S, Kreitz S, Sergeeva M, Englbrecht M, et al. Association of brain functional magnetic resonance activity with response to tumor necrosis factor inhibition in rheumatoid arthritis. Arthritis Rheum. 2013;65(2):325-33.

29. Ignatowski TA, Spengler RN. Tumor necrosis factor-alpha: presynaptic sensitivity is modified after antidepressant drug administration. Brain Res. 1994;665(2):293-9.

30. Ignatowski TA, Noble BK, Wright JR, Gorfien JL, Heffner RR, Spengler RN. Neuronal-associated tumor necrosis factor (TNF alpha): its role in noradrenergic functioning and modification of its expression following antidepressant drug administration. J Neuroimmunol. 1997;79(1):84-90.

31. Vezzani A. Epilepsy and inflammation in the brain: overview and pathophysiology. Epilepsy Curr. 2014;14(1 Suppl):3-7. 
32. Tobinick E, Rodriguez-Romanacce H, Levine A, Ignatowski TA, Spengler RN. Immediate neurological recovery following perispinal etanercept years after brain injury. Clin Drug Investig. 2014;34(5):361-6.

33. Sedger LM, McDermott MF. TNF and TNF-receptors: from mediators of cell death and inflammation to therapeutic giantspast, present and future. Cytokine Growth Factor Rev. 2014; doi:10.1016/j.cytogfr.2014.07.016.

34. Pribiag H, Stellwagen D. Neuroimmune regulation of homeostatic synaptic plasticity. Neuropharmacology. 2014;78:13-22.

35. Olmos G, Llado J. Tumor necrosis factor alpha: a link between neuroinflammation and excitotoxicity. Mediat inflamm. 2014; 2014:861231.

36. Cheng X, Shen Y, Li R. Targeting TNF: a therapeutic strategy for Alzheimer's disease. Drug Discov Today. 2014; doi:10. 1016/j.drudis.2014.06.029.

37. Santello M, Volterra A. TNF-alpha in synaptic function: switching gears. Trends Neurosci. 2012;35(10):638-47.

38. Whitlock DR. Comment on: "Perispinal etanercept for poststroke neurological and cognitive dysfunction: scientific rationale and current evidence". CNS Drugs. 2014. doi:10.1007/ s40263-014-0211-1.

39. Hill AB. The environment and disease: association or causation? Proc R Soc Med. 1965;58:295-300.

40. Howick J, Glasziou P, Aronson JK. The evolution of evidence hierarchies: what can Bradford Hill's 'guidelines for causation' contribute? J R Soc Med. 2009;102(5):186-94.

41. Kaplan BJ, Giesbrecht G, Shannon S, McLeod K. Evaluating treatments in health care: the instability of a one-legged stool. BMC Med Res Methodol. 2011;11:65.

42. Williams JK. Understanding evidence-based medicine: a primer. Am J Obstet Gynecol. 2001;185(2):275-8.

43. Glasziou P, Chalmers I, Rawlins M, McCulloch P. When are randomised trials unnecessary? Picking signal from noise. BMJ. 2007;334(7589):349-51.

44. OCEBM Levels of Evidence Working Group. The Oxford 2011 levels of evidence. Oxford Centre for Evidence-Based Medicine. 2011. http://www.cebm.net/index.aspx?o=5653. Accessed 9 Oct 2014.

45. Baeten D, van Hagen PM. Use of TNF blockers and other targeted therapies in rare refractory immune-mediated inflammatory diseases: evidence-based or rational? Ann Rheum Dis. 2010;69(12):2067-73.

46. US FDA. Guidance for clinical investigators, spon'sors, and IRBs. Investigational new drug applications (INDs) - determining whether human research studies can be conducted without an IND. 2013. http://www.fda.gov/downloads/Drugs/ Guidances/UCM229175.pdf. Accessed 9 Oct 2014.

47. Dacks PA, Bennett DA, Fillit HM. Evidence needs to be translated, whether or not it is complete. JAMA Neurol. 2014;71(2):137-8.

48. Howick J, Glasziou P, Aronson JK. Evidence-based mechanistic reasoning. J R Soc Med. 2010;103(11):433-41.

49. Concato J. Observational versus experimental studies: what's the evidence for a hierarchy? NeuroRx. 2004;1(3):341-7.

50. Concato J, Shah N, Horwitz RI. Randomized, controlled trials, observational studies, and the hierarchy of research designs. N Engl J Med. 2000;342(25):1887-92.

51. Trudeau DL. The value of observational studies in neurotherapy. J Neurother. 2001;4(3):1-4.

52. Grossman J, Mackenzie FJ. The randomized controlled trial: gold standard, or merely standard? Perspect Biol Med. 2005;48(4):516-34.

53. Demonaco HJ, Ali A, Hippel E. The major role of clinicians in the discovery of off-label drug therapies. Pharmacotherapy. 2006;26(3):323-32.
54. Tobinick EL. The value of drug repositioning in the current pharmaceutical market. Drug News Perspect. 2009;22(2): 119-25.

55. Elliott MJ, Maini RN, Feldmann M, Long-Fox A, Charles P, Bijl $\mathrm{H}$, et al. Repeated therapy with monoclonal antibody to tumour necrosis factor alpha (cA2) in patients with rheumatoid arthritis. Lancet. 1994;344(8930):1125-7.

56. Sackett DL, Rosenberg WM, Gray JA, Haynes RB, Richardson WS. Evidence based medicine: what it is and what it isn't. BMJ. 1996;312(7023):71-2.

57. Vandenbroucke JP. Case reports in an evidence-based world. J R Soc Med. 1999;92(4):159-63.

58. Vandenbroucke JP. In defense of case reports and case series. Ann Intern Med. 2001;134(4):330-4.

59. Kiene H, Hamre HJ, Kienle GS. In support of clinical case reports: a system of causality assessment. Glob Adv Health Med. 2013;2(2):64-75.

60. Smith GC, Pell JP. Parachute use to prevent death and major trauma related to gravitational challenge: systematic review of randomised controlled trials. BMJ. 2003;327(7429):1459-61.

61. Tobinick E. Perispinal etanercept produces rapid improvement in primary progressive aphasia: identification of a novel, rapidly reversible TNF-mediated pathophysiologic mechanism. Medscape J Med. 2008;10(6):135.

62. Tobinick E, Rodriguez-Romanacce H, Levine A, Ignatowski TA, Spengler RN. Immediate neurological recovery following perispinal etanercept years after brain injury. Clin Drug Invest 2014; 34(5):361-66.

63. Coelho SC, Bastos-Pereira AL, Fraga D, Chichorro JG, Zampronio AR. Etanercept reduces thermal and mechanical orofacial hyperalgesia following inflammation and neuropathic injury. Eur J Pain. 2014;18(7):957-67.

64. Cohen SP, Bogduk N, Dragovich A, Buckenmaier CC 3rd, Griffith S, Kurihara C, et al. Randomized, double-blind, placebo-controlled, dose-response, and preclinical safety study of transforaminal epidural etanercept for the treatment of sciatica. Anesthesiology. 2009;110(5):1116-26.

65. Freeman BJ, Ludbrook GL, Hall S, Cousins M, Mitchell B, Jaros $\mathrm{M}$, et al. Randomized, double-blind, placebo-controlled, trial of transforaminal epidural etanercept for the treatment of symptomatic lumbar disc herniation. Spine. 2013;38(23):1986-94.

66. Holmes C, Butchart J, Wolfe L, Davies L, Dodge S, Lewsey I, et al. The safety and tolerability of etanercept in Alzheimer's disease (STEADI-09): a phase II double blind randomised placebo controlled trial 2014. Copenhagen: Alzheimer's Association International Conference; 2014.

67. Iwatsuki K, Arai T, Ota H, Kato S, Natsume T, Kurimoto S, et al. Targeting anti-inflammatory treatment can ameliorate injury-induced neuropathic pain. PloS One. 2013;8(2):e57721.

68. Kato K, Kikuchi S, Shubayev VI, Myers RR. Distribution and tumor necrosis factor-alpha isoform binding specificity of locally administered etanercept into injured and uninjured rat sciatic nerve. Neuroscience. 2009;160(2):492-500.

69. Ohtori S, Miyagi M, Eguchi Y, Inoue G, Orita S, Ochiai N, et al. Epidural administration of spinal nerves with the tumor necrosis factor-alpha inhibitor, etanercept, compared with dexamethasone for treatment of sciatica in patients with lumbar spinal stenosis: a prospective randomized study. Spine. 2012;37(6): 439-44.

70. Olmarker K, Rydevik B. Selective inhibition of tumor necrosis factor-alpha prevents nucleus pulposus-induced thrombus formation, intraneural edema, and reduction of nerve conduction velocity: possible implications for future pharmacologic treatment strategies of sciatica. Spine. 2001;26(8):863-9.

71. Sainoh T, Orita S, Yamauchi K, Suzuki M, Sakuma Y, Kubota $\mathrm{G}$, et al. Intradiscal administration of tumor necrosis factor- 
alpha inhibitor, etanercept, clinically improves intractable discogenic low back pain. Glob Spine J. 2014. doi:10.1055/s-00341376544.

72. Shen CH, Tsai RY, Shih MS, Lin SL, Tai YH, Chien CC, et al. Etanercept restores the antinociceptive effect of morphine and suppresses spinal neuroinflammation in morphine-tolerant rats. Anesth Analg. 2011;112(2):454-9.

73. Sommer C, Schafers M, Marziniak M, Toyka KV. Etanercept reduces hyperalgesia in experimental painful neuropathy. J Peripher Nerv Syst. 2001;6(2):67-72.

74. Tobinick E. Perispinal etanercept for neuroinflammatory disorders. Drug Discov Today. 2009;14(3-4):168-77.

75. Tobinick E. Author's reply to Page. "Selective TNF inhibition for chronic stroke and traumatic brain injury: an observational study involving 629 consecutive patients treated with perispinal etanercept". CNS Drugs. 2013;27(5):399-402.

76. Tobinick EL. Targeted etanercept for discogenic neck pain: uncontrolled, open-label results in two adults. Clin Ther. 2003;25(4):1211-8.

77. Watanabe K, Yabuki S, Sekiguchi M, Kikuchi S, Konno S. Etanercept attenuates pain-related behavior following compression of the dorsal root ganglion in the rat. Eur Spine J. 2011;20(11):1877-84.

78. Zanella JM, Burright EN, Hildebrand K, Hobot C, Cox M, Christoferson L, et al. Effect of etanercept, a tumor necrosis factor-alpha inhibitor, on neuropathic pain in the rat chronic constriction injury model. Spine. 2008;33(3):227-34.

79. Tobinick EL. Targeted etanercept for treatment-refractory pain due to bone metastasis: two case reports. Clin Ther. 2003;25(8): 2279-88.

80. Tobinick E, Vega CP. The cerebrospinal venous system: anatomy, physiology, and clinical implications. Med Gen Med. 2006;8(1):53.

81. Tobinick E. Tumour necrosis factor modulation for treatment of Alzheimer's disease: rationale and current evidence. CNS Drugs. 2009;23(9):713-25.

82. Ignatowski TA, Spengler RN, Dhandapani KM, Folkersma H, Butterworth RF, Tobinick E. Perispinal etanercept for poststroke neurological and cognitive dysfunction: scientific rationale and current evidence. CNS Drugs. 2014.

83. Ye J, Jiang R, Cui M, Zhu B, Sun L, Wang Y, et al. Etanercept reduces neuroinflammation and lethality in mouse model of Japanese encephalitis. J Infect Dis. 2014;210(6):875-89.

84. Winkelstein BA, Allen KD, Setton LA. Chapter 19: intervertebral disc herniation: pathophysiology and emerging therapies. In: Shapiro IM, Risbud MV, editors. The intervertebral disc. Wien: Springer; 2014.

85. Wilcox KS, Vezzani A. Does brain inflammation mediate pathological outcomes in epilepsy? Adv Exp Med Biol. 2014;813:169-83.

86. Wang K, Liu B, Ma J. Research progress in traumatic brain penumbra. Chin Med J. 2014;127(10):1964-8.

87. Walters ET. Neuroinflammatory contributions to pain after SCI: roles for central glial mechanisms and nociceptor-mediated host defense. Exp Neurol. 2014;258C:48-61.

88. Viviani B, Boraso M, Marchetti N, Marinovich M. Perspectives on neuroinflammation and excitotoxicity: a neurotoxic conspiracy? Neurotoxicology. 2014;43:10-20.

89. Topdag M, Iseri M, Topdag DO, Kokturk S, Ozturk M, Iseri P. The effect of etanercept and methylprednisolone on functional recovery of the facial nerve after crush injury. Otol Neurotol. 2014;35(7):1277-83.

90. Sun Q, Hampel H, Blennow K, Lista S, Levey A, Tang B, et al. Increased plasma TACE activity in subjects with mild cognitive impairment and patients with Alzheimer's disease. J Alzheimer's Dis. 2014;41(3):877-86.
91. Siniscalchi A, Gallelli L, Malferrari G, Pirritano D, Serra R, Santangelo E, et al. Cerebral stroke injury: the role of cytokines and brain inflammation. J Basic Clin Physiol Pharmacol. 2014;25(2):131-7.

92. Ohtori S, Inoue G, Miyagi M, Takahashi K. Pathomechanisms of discogenic low back pain in humans and animal models. Spine J. 2014;. doi:10.1016/j.spinee.2013.07.490.

93. Najem D, Bamji-Mirza M, Chang N, Liu QY, Zhang W. Insulin resistance, neuroinflammation, and Alzheimer's disease. Rev Neurosci. 2014;25(4):509-25.

94. Kathirvelu B, Carmichael ST. Intracerebral hemorrhage in mouse models: therapeutic interventions and functional recovery. Metab Brain Dis. 2014;. doi:10.1007/s11011-014-9559-7.

95. Griessenauer CJ, Raborn J, Foreman P, Shoja MM, Loukas M, Tubbs RS. Venous drainage of the spine and spinal cord: a comprehensive review of its history, embryology, anatomy, physiology, and pathology. Clin Anat. 2014;. doi:10.1002/ca. 22354.

96. Gisondi P, Sala F, Alessandrini F, Avesani V, Zoccatelli G, Beltramello A, et al. Mild cognitive impairment in patients with moderate to severe chronic plaque psoriasis. Dermatology. 2014;228(1):78-85.

97. Ferreira ST, Clarke JR, Bomfim TR, De Felice FG. Inflammation, defective insulin signaling, and neuronal dysfunction in Alzheimer's disease. Alzheimer's dement J Alzheimer's Assoc. 2014;10(1S):S76-83.

98. Faingold CL. Network control mechanisms: cellular inputs, neuroactive substances, and synaptic changes. In: Faingold CL, Blumenfeld $\mathrm{H}$, editors. Neuronal networks in brain function. CNS Disorders, and Therapeutics: Elsevier; 2014.

99. Ekici MA, Uysal O, Cikriklar HI, Ozbek Z, Turgut Cosan D, Baydemir $\mathrm{C}$, et al. Effect of etanercept and lithium chloride on preventing secondary tissue damage in rats with experimental diffuse severe brain injury. Eur Rev Med Pharmacol Sci. 2014;18(1):10-27.

100. Detrait ER, Danis B, Lamberty Y, Foerch P. Peripheral administration of an anti-TNF-alpha receptor fusion protein counteracts the amyloid induced elevation of hippocampal TNFalpha levels and memory deficits in mice. Neurochem Int. 2014;. doi:10.1016/j.neuint.2014.04.001.

101. Yoshiyama Y, Lee VM, Trojanowski JQ. Therapeutic strategies for tau mediated neurodegeneration. J Neurol Neurosurg Psychiatry. 2013;84(7):784-95.

102. Works MG, Koenig JB, Sapolsky RM. Soluble TNF receptor 1 -secreting ex vivo-derived dendritic cells reduce injury after stroke. J Cereb Blood Flow Metab. 2013;33(9):1376-85.

103. Waters RJ, Murray GD, Teasdale GM, Stewart J, Day I, Lee RJ, et al. Cytokine gene polymorphisms and outcome after traumatic brain injury. J Neurotrauma. 2013;30(20):1710-6.

104. Swardfager W, Winer DA, Herrmann N, Winer S, Lanctot KL. Interleukin-17 in post-stroke neurodegeneration. Neurosci Biobehav Rev. 2013;37(3):436-47.

105. Shi X, Zhou W, Huang H, Zhu H, Zhou P, Zhu H, et al. Inhibition of the inflammatory cytokine tumor necrosis factor-alpha with etanercept provides protection against lethal H1N1 influenza infection in mice. Critical Care. 2013;17(6):R301.

106. Miller ZA, Rankin KP, Graff-Radford NR, Takada LT, Sturm VE, Cleveland CM, et al. TDP-43 frontotemporal lobar degeneration and autoimmune disease. J Neurol Neurosurg Psychiatry. 2013;84(9):956-62.

107. Lei B, Dawson HN, Roulhac-Wilson B, Wang H, Laskowitz DT, James ML. Tumor necrosis factor alpha antagonism improves neurological recovery in murine intracerebral hemorrhage. J Neuroinflamm. 2013;10(1):103.

108. Kaufman EL, Carl A. Biochemistry of back pain. Open Spine J. 2013;5:12-8. 
109. Johnson VE, Stewart JE, Begbie FD, Trojanowski JQ, Smith $\mathrm{DH}$, Stewart W. Inflammation and white matter degeneration persist for years after a single traumatic brain injury. Brain. 2013; 136(Pt 1):28-42.

110. Furst DE, Fleischman R, Kalden J, Kavanaugh A, Sieper J, Mease P, et al. Documentation of off-label use of biologics in rheumatoid arthritis. Ann Rheum Dis. 2013;72(Suppl 2): ii35-51.

111. Efrati S, Fishlev G, Bechor Y, Volkov O, Bergan J, Kliakhandler $\mathrm{K}$, et al. Hyperbaric oxygen induces late neuroplasticity in post stroke patients: randomized, prospective trial. PloS One. 2013;8(1):e53716

112. Clark IA, Vissel B. Treatment implications of the altered cytokine-insulin axis in neurodegenerative disease. Biochem Pharmacol. 2013;86(7):862-71.

113. Chio CC, Chang $\mathrm{CH}$, Wang $\mathrm{CC}$, Cheong CU, Chao CM, Cheng $\mathrm{BC}$, et al. Etanercept attenuates traumatic brain injury in rats by reducing early microglial expression of tumor necrosis factoralpha. BMC Neurosci. 2013;14(1):33.

114. Cheong CU, Chang CP, Chao CM, Cheng BC, Yang CZ, Chio CC. Etanercept attenuates traumatic brain injury in rats by reducing brain TNF-alpha contents and by stimulating newly formed neurogenesis. Mediat Inflamm. 2013;2013:620837.

115. Butterworth RF. The liver-brain axis in liver failure: neuroinflammation and encephalopathy. Nature Rev Gastroenterol Hepatol. 2013;10(9):522-8.

116. Brambilla L, Martorana F, Rossi D. Astrocyte signaling and neurodegeneration: new insights into CNS disorders. Prion. 2013;7(1):28-36.

117. Boivin N, Menasria R, Piret J, Rivest S, Boivin G. The combination of valacyclovir with an anti-TNF alpha antibody (etanercept) increases survival rate compared to antiviral therapy alone in a murine model of herpes simplex virus encephalitis. Antivir Res. 2013;100(3):649-53.

118. Blaylock RL. Immunology primer for neurosurgeons and neurologists part 2: innate brain immunity. Surg Neurol Int. 2013;4:118.

119. Bai L, Song N, Yu J, Tan L, Shen Y, Xie J, et al. Elevated plasma levels of soluble TNFRs and TACE activity in Alzheimer's disease patients of northern Han Chinese descent. Curr Alzheimer Res. 2013;10(1):57-62.

120. Williams M, Coyle JT. Historical perspectives on the discovery and development of drugs to treat neurological disorders. In: Barrett JE, Coyle JT, Williams M, editors. Translational neuroscience: applications in psychiatry, neurology, and neurodevelopmental disorders. New York: Cambridge University Press; 2012. p. $129-48$.

121. Clark I. New hope for survivors of stroke and traumatic brain injury. CNS Drugs. 2012;26(12):1071-2.

122. Clark I, Atwood C, Bowen R, Paz-Filho G, Vissel B. Tumor necrosis factor-induced cerebral insulin resistance in Alzheimer's disease links numerous treatment rationales. Pharmacol Rev. 2012;64(4):1004-26.

123. Hrobjartsson A, Gotzsche PC. Is the placebo powerless? An analysis of clinical trials comparing placebo with no treatment. N Engl J Med. 2001;344(21):1594-602.

124. Hrobjartsson A, Gotzsche PC. Placebo interventions for all clinical conditions. Cochrane Database Syst Rev. 2010;(1): CD003974.

125. Hachinski V, Donnan GA, Gorelick PB, Hacke W, Cramer SC, Kaste M, et al. Stroke: working toward a prioritized world agenda. Stroke. 2010;41(6):1084-99. 